\title{
Editorial
}

\section{La corrupción, enemiga de la transición democrática}

Las sociedades centroamericanas iniciaron, a finales de la década de 1980, una transición de los regímenes autoritarios de signo militar, hacia gobiernos encabezados por civiles. La década siguiente estuvo signada por la cesación de los conflictos bélicos internos y el paso a regímenes democráticos, en los cuales los otrora enemigos en el campo de batalla pasaron a competir electoralmente. Se inauguraba, junto a las formalidades demo$\checkmark$ cráticas, una serie de instituciones para proteger los derechos de la ciudadanía y vigilar el desempeño de las entidades del Estado. En teoría, la región tenía las condiciones ideales para consumar y consolidar su transición hacia la democracia.

Pero este camino no fue fácil como se creía. En muchos de los casos, las instituciones democráticas (contralorías, defensores del pueblo, entre otros) se ven seriamente amenazadas por problemas heredados del pasado. Los procesos de paz de las naciones que experimentaron conflictos armados no erradicaron la impunidad de los grupos militares involucrados en violaciones 
a los derechos humanos. Estos grupos probaron su capacidad para adaptarse a los nuevos tiempos democráticos, y aunque su protagonismo político ha bajado seriamente de perfil, todavía tienen un nivel de incidencia importante en la vida pública. Por otro lado, las élites gobernantes suelen oponer una gran resistencia a la alternancia en el poder.

Ello explica que la institucionalidad democrática se vea afec$\checkmark$ tada por aquellos grupos sociales que no están interesados en ceder privilegios ni espacios de poder.. Uno de los puntos más vulnerables de esa institucionalidad es la corrupción en las entidades del Estado. El largo y penoso proceso de desafuero contra el ex presidente Arnoldo Alemán en Nicaragua y la huida hacia el extranjero del saliente mandatario guatemalteco, Alfonso Portillo, son muestras de que la corrupción se ha enseñoreado en la vida pública de las naciones centroamericanas.

$\checkmark$ Es preocupante ver cómo las mismas instituciones que se han diseñado para salvaguardar los derechos de la ciudadanía se utilizan para mantener actos de corrupción en la impunidad. En una de las repúblicas centroamericanas, el ente contralor supedita sus acciones a arreglos partidarios oscuros; en otra, la credibilidad internacional del país se ha visto seriamente erosionada.

\section{Un mandato plagado de dudas}

La duda ha caracterizado al desempeño de Portillo al frente de la primera magistratura de su país. Las acusaciones de corrupción y de lavado de dinero en cuentas bancarias de Panamá y de "paraísos fiscales" que pesaron sobre él y sobre sus allegados, pusieron la credibilidad de su gobierno en un serio cuestionamiento, llegando a afectar a la inversión extranjera. Cabe recordar que esto se conoció gracias a una investigación periodística hecha en conjunto por los diarios Siglo XXI, de Guatemala y La Estrella, de Panamá, y que dejó descubierta una trama en la que también eran partícipes el entonces vicepresidente, Juan 
Francisco Reyes López; el hijo de éste, Juan Francisco Reyes Wyld y el secretario privado de la Presidencia, Julio César Girón Barillas, de quienes se conoció que habían abierto trece cuentas bancarias en Panamá y Estados Unidos y creado cuatro empresas en Panamá y una en Islas Vírgenes. Estas empresas, bajo el manto de la comercialización de petróleo, servían para lavar dinero. También estuvo involucrado en este caso el cuñado de Portillo. En otras latitudes, por casos mucho menos graves, cualquier funcionario presenta su renuncia y se pone a disposición de las autoridades judiciales, de tal suerte que la institucionalidad del país no se vea perjudicada por el escándalo.

Sin embargo, el ex mandatario no se comprometió seriamente en despejar las dudas, sino que contribuyó a alimentarlas. Portillo también se burló de la frágil institucionalidad guatemalteca, facilitando que el ex dictador Efraín Ríos Montt participara en la vida política - primero, como presidente del parlamento y después como candidato a la presidencia de la república-, a pesar de que ello le estaba legalmente prohibido.

Otro caso grave de corrupción de alto nivel es el del ex presidente nicaragüense Arnoldo Alemán, quien se escudó, primero en su fuero de diputado y posteriormente en la inmunidad que le confería su calidad de miembro del Parlamento Centroamericano (PARLACEN). La lección que dejó el caso fue que la captura del ex mandatario hubiera sido imposible sin la participación activa de la ciudadanía, que se movilizó para exigir justicia, y el compromiso del gobierno nicaragüense.

\section{La corrupción mina la institucionalidad democrática}

Como decíamos, la impunidad de los corruptos está íntimamente ligada a la impunidad de los que tradicionalmente han detentado el poder político, entre ellos, los que tuvieron el poder militar en el pasado. Aunque su omnipotencia sea cosa del pasado, aunque su poder no sea ya la sombra ominosa que pesaba sobre toda la vida pública, estos sectores han logrado 
viciar la institucionalidad democrática de naciones que, como la mayoría de Centroamérica, han emprendido una transición de las dictaduras militares, pasando por democracias restringidas o tuteladas - por ejemplo, los gobiernos civiles de Guatemala, El Salvador y Honduras en las postrimerías de los ochenta-, hacia democracias endebles o francamente amenazadas.

Esas democracias incipientes no han consolidado ni las instituciones ni los mecanismos legales para perseguir la corrupción. Citamos un párrafo del documento Corrupción presidencial en Centroamérica, firmado por Jaime López, de Probidad, donde se explica que no hace falta cometer latrocinios propios de un Arnoldo Alemán para que la corrupción se enquiste en las instituciones estatales, sino que también se puede contribuir a ello impidiendo que las entidades contraloras funcionen a cabalidad.

«Lamentablemente es difícil diferenciar a la única mujer presidenta latinoamericana, Mireya Moscoso, quien gobierna Panamá desde septiembre de 1999, de los demás mandatarios de la región. La persistente conducta de bloquear medidas contra la corrupción, la forma en que se favorece o encubre a quienes comenten actos de esa naturaleza y la actitud de desacreditación contra quienes hacen críticas hacia su gestión, son las características de su régimen. Por ejemplo, la Fiscalía sometió a consideración un proyecto de ley que introducía nuevos delitos en el Código Penal, asociados con el lavado de dinero. La reforma, que fue aprobada por la Asamblea Legislativa, era novedosa porque eliminaba el requisito de prueba sumaria para la presentación de denuncias por enriquecimiento ilícito contra funcionarios. Esto abría el camino para que los ciudadanos pudieran presentar denuncias de esa naturaleza. A inicios de mayo del 2003 Moscoso objetó la reforma y devolvió el proyecto de Ley a la Asamblea, órgano que terminó sometiéndose al criterio presidencial», afirma López.

Observemos una cosa que sobresale en el párrafo anterior: tanto la excesiva concentración de poder en manos del Ejecuti- 
vo, propia de regímenes presidencialistas, como el escaso nivel de independencia de los órganos del Estado, permite que tanto un partido, como una elite política y económica puedan hacer con el erario público lo que quieran. Ello garantiza un nivel de impunidad sumamente comparable a aquella de la que gozaban los estamentos militares o los grupos oligárquicos dominantes en el pasado.

\section{El PARLACEN y su descrédito}

El PARLACEN, al conferirle a los ex mandatarios centroamericanos la calidad de "miembros por derecho propio", abrió un resquicio para la impunidad de los responsables de la corrupción estatal. Un ex presidente acusado por desfalco en perjuicio del erario público logra mantenerse al margen de la ley gracias a su nueva calidad de diputado centroamericano. La inmunidad que otorga el PARLACEN ha sido objeto de abusos, al grado que la entidad parlamentaria está seriamente cuestionada y su existencia parece tener los días contados.

En el ámbito interno, los cargos públicos y la inmunidad que algunos de estos otorgan, ofrecen resguardo para los responsables de las corruptelas. Igualmente grave resulta el hecho que, culturalmente hablando, el hecho de la corrupción parece ser algo "normal" a ojos de la ciudadanía: se ve como algo "ordinario" el que alguien se valga de su nombramiento para enriquecerse o para aumentar su fortuna personal. Esto es un resabio de la mentalidad autoritaria que heredamos del pasado. Sin superar esto, será quimérico lograr que nuestras sociedades erradiquen esa tara que corroe los endebles cimientos de su institucionalidad democrática. 